\title{
Contribution of progesterone, follicle stimulating hormone and glucocorticoids in survival of serum-free cultured granulosa cell explants
}

\author{
S Mussche and $K \mathbf{D}^{\prime}$ Herde \\ Department of Anatomy, Embryology, Histology and Medical Physics, Ghent University, Faculty of Medicine and Health Sciences, B-9000 Ghent, Belgium \\ (Requests for offprints should be addressed to S Mussche, Department of Anatomy, Embryology, Histology and Medical Physics, Faculty of Medicine and \\ Health Sciences, Ghent University, Godshuizenlaan 4, B-9000 Gent, Belgium; Email: s.mussche@rug.ac.be)
}

\begin{abstract}
To investigate the role of progesterone ( $\mathrm{P} 4)$ as a survival factor in quail granulosa cell explants, P4 content was determined under various conditions and correlated with apoptotic indexes (AIs) evaluated by $2^{\prime}, 6^{\prime}$-diamidino-2phenylindole (DAPI)-staining. Analysis of serum-free cultures from 24 to $96 \mathrm{~h}$ shows decreased P4 levels in the medium paralleled by increasing AI. Inhibiting apoptosis by gonadotropic support (FSH, $100 \mathrm{ng} / \mathrm{ml}$ ) stimulates a 3-fold increase of the $\mathrm{P} 4$ level in the medium $(83.49 \pm 8.69$ vs $26.31 \pm 1.61 \mathrm{ng} / \mathrm{ml}$ in serum-free controls) together with a significant decrease in AI from $8 \cdot 81 \pm 1 \cdot 06 \%$ in serum-free controls to $3 \cdot 50 \pm 0 \cdot 72 \%$. Substantial evidence for $\mathrm{P} 4$ as an autocrine/paracrine survival factor can be inferred from experiments with aminoglutethimide (AG, $1 \mathrm{mM})$ and RU486 (20 $\mu \mathrm{M})$. Blocking P4 synthesis by AG causes a 2-fold increase in apoptosis from $6 \cdot 08 \pm 0.67 \%$ in serum-free controls to $12 \cdot 53 \pm 1 \cdot 60 \%$. Blocking P4 receptors by RU486 causes a similar increase in $\mathrm{AI}(3.02 \pm 0.98 \%$ in serum-free controls
\end{abstract}

to $17 \cdot 07 \pm 3 \cdot 20 \%$ ) and about a $50 \%$ decrease in $\mathrm{P} 4$. The effect of RU486 could be attenuated by exogenous P4 but not by dexamethasone indicating selective binding of $\mathrm{P} 4$ to the progesterone receptor. Dexamethasone treatment promotes survival without affecting P4 levels. In further support of an autocrine/paracrine action for P4 in the granulosa cells, both the A and B form of the avian P4 receptor (PR) are identified in vivo and in vitro by Western blotting. Exogenous administration of P4 only affects survival when endogenous $\mathrm{P} 4$ synthesis is blocked or after $48 \mathrm{~h}$ of serum-free culture when endogenous $\mathrm{P} 4$ production is very low. Because FSH also affects survival when its stimulatory effect on $\mathrm{P} 4$ synthesis is blocked by AG (AI decrease from $6.08 \pm 0.67 \%$ in serum-free controls to $1.64 \pm 0.71 \%$ in $\mathrm{FSH}+\mathrm{AG}$ treated) it is proposed that (1) P4 is an autocrine/paracrine survival factor in the preovulatory granulosa and (2) FSH mediates both P4-dependent and P4-independent survival pathways.

Journal of Endocrinology (2001) 169, 321-331

\section{Introduction}

Once follicles start to grow they are either selected for ovulation or, like the majority of them, they become atretic. The underlying molecular mechanism for follicle degeneration is apoptosis (or programmed cell death) as shown for all vertebrate species analysed so far (Tilly et al. 1997) and even for invertebrates (Criel \& D'Herde 1996). Follicular atresia is initiated by programmed cell death of the somatic cells surrounding the oocyte: the granulosa cells (Tilly et al. 1997).

The major regulators of follicle development are gonadotropins. Gonadotropins stimulate granulosa cells to secrete various growth factors which in turn modulate ovarian steroidogenesis and other survival factors through at least three separate signalling pathways involving protein A kinases, protein $\mathrm{C}$ kinases and tyrosine kinases; of these the adenylyl cyclase-cAMP-A kinase pathway is the most studied (Hsueh et al. 1984, Richards 1994, Chun \& Hsueh 1998).

The effects of oestrogens and androgens on granulosa cell survival are well documented (Hsueh et al. 1984, Billig et al. 1994, Hsu \& Hsueh 1997). Several studies suggest that $\mathrm{P} 4$, the major steroidal output of the preovulatory granulosa, can regulate granulosa cell proliferation (Chaffkin et al. 1992) and inhibit apoptosis in granulosa cultures (Luciano et al. 1994). The survival effect of the paracrine factor epidermal growth factor (EGF) is also mediated by P4 (Luciano et al. 1994) and P4 itself stimulates synthesis of the autocrine survival factor bovine fibroblast growth factor (bFGF) in rat granulosa cells (Peluso \& Pappalardo 1999). For the corpus luteum, another target tissue of $\mathrm{P} 4$ action, it was recently shown that the survival effect of $\mathrm{P} 4$ involves downregulation of 
Fas expression, a member of the cell death receptor family (Kuranaga et al. 2000).

In support of a direct ovarian action for $\mathrm{P} 4$, specific $\mathrm{P} 4$ receptors (PRs) existing as $\mathrm{A}$ and $\mathrm{B}$ forms have been demonstrated in the avian ovary with the highest amount in the F1 follicle (Yoshimura \& Bahr 1991, Isola et al. 1987a). Isola and colleagues (Isola 1987, Isola et al. 1987a,b) describe a nuclear localization of the PR in chick oviduct and some unoccupied PRs in the cytosol (Isola et al. 1986). As conflicting data exist about the localization of unoccupied receptors, Clark \& Markaverich (1988) suggested that the PRs in the nucleus are in a state of equilibrium with those in the cytoplasm, which results in a small percentage of receptors being located in the cytoplasm. Occupied PRs are always found in the nucleus where they fulfil their role as a transcription factor. The central role of $\mathrm{P} 4$ and the $\mathrm{PR}$ in mammary development is underlined by the many pleiotropic reproductive abnormalities such as anovulation, limited mammary gland development, hyperplasia, as well as neuroendocrine defects, found in PR knockout mice (Lydon et al. 1995, Chappell et al. 1997). In rat follicles, PR mRNA is not expressed until after the pre-ovulatory luteinising hormone (LH) surge (Park \& Mayo 1991, Natraj \& Richards 1993). Despite this absence of the PR prior to the LH surge, P4 is able to maintain the viability of rat granulosa cells possibly through a membrane P4-binding protein (Peluso 1997, Peluso \& Pappalardo 1999).

In the present study an in vitro model was used consisting of serum-free culture of granulosa cell explants derived from the vegetative pole of the largest preovulatory follicle. In this system the granulosa epithelial explants remain sandwiched between their native basement and vitelline membrane, in this way, cell-cell interaction like metabolic exchanges and transport of small molecules through gap junctions (D'Herde \& Leybaert 1997, Farioli-Vecchioli et al. 2000) is maintained. This model thus closely resembles normal in vivo-like tissue structure.

In the present study it was analysed whether (1) P4 acts as an important component of the follicle stimulating hormone (FSH)-stimulated anti-apoptotic cascade, (2) the survival effect of FSH is entirely P4-dependent. Therefore after detecting PR isoforms at various culture stages, the correlation was examined between apoptotic indexes and P4 levels under basal serum-free conditions, under gonadotropic support and in conditions where $\mathrm{P} 4$ synthesis was inhibited or its effect was abrogated through blockade of its receptors.

In addition, the role of dexamethasone in survival was addressed. Although it is known that glucocorticoids highly augment CAMP-stimulated progesterone production in several granulosa models (Hosokawa et al. 1998), its regulatory role in survival is not well documented (Makrigiannakis et al. 2000).

\section{Materials and Methods}

\section{Animals}

Granulosa cell explants were prepared from the largest (F1) pre-ovulatory follicle of the adult Japanese quail (Coturnix coturnix japonica). The animals were reared under continuous artificial illumination, with food (fresh lettuce and complete breeding food, Biofor AVEVE, Belgium) and water ad libitum. Animal care procedures were conducted in accordance with the guidelines set by the European Community Council Directives 86/6091 EEC.

\section{Isolation and culture of granulosa cell explants}

The monolayered granulosa layer from the largest preovulatory follicle (F1) was isolated from the follicle wall in Krebs-Ringer solution according to the technique described by Gilbert et al. (1977). Farioli-Vecchioli et al. (2000) defined three regions in quail granulosa explants which are analogous to those defined in chicken by Tischkau \& Bahr (1996). The area of the transition region between the animal and vegetal pole which is in close contact with the animal pole contains several cell proliferatory factors which inhibit $\mathrm{P} 4$ production by chicken granulosa cells (Tischkau \& Bahr 1996). Therefore the animal pole and transition region were selectively removed from the rest of the granulosa cell (GC) explant. The morphology, mitotic rate and other factors in these latter regions of the granulosa layer differ from those in the vegetal pole region and probably represent a subpopulation as described for hen (Marrone \& Crissman 1988) and rat granulosa cells (Peluso 1997). The remaining granulosa from the vegetal pole region of circa $5 \cdot 8 \mathrm{~cm}^{2}$ was divided into smaller squares of circa $4 \mathrm{~mm}^{2}$, followed by culture in $35 \mathrm{~mm}$ Petri dishes under serum-free conditions in a $38^{\circ} \mathrm{C}$ incubator. Explants were cultured for various time periods depending on the experiment type. Culture times of $24 \mathrm{~h}$ were used for evaluation of AG, RU486, dexamethasone and FSH effects; to correlate apoptotic indexes with $\mathrm{P} 4$ levels in the medium granulosa explants cultured for 24, 48, 72 and $96 \mathrm{~h}$ were analysed. GC explants were cultured for up to $72 \mathrm{~h}$ for $\mathrm{P} 4$ rescuing experiments and PR Western blotting. Explants were cultured in filter-sterilized M199 (Sigma, cat. no. M-0393, Bornem, Belgium) at $\mathrm{pH} 7 \cdot 4$, supplemented with $0 \cdot 1 \% \mathrm{w} / \mathrm{v}$ bovine serum albumin fraction V (Sigma, cat. no. A-4503, Bornem, Belgium), $10 \mathrm{mM}$ HEPES (Acros, Geel, Belgium), 1\% v/v penicillin-streptomycin (Paisley, UK) and $4 \mathrm{mM}$ sodium hydrogen carbonate.

\section{Reagents and hormones}

Sheep pituitary FSH $(100 \mathrm{ng} / \mathrm{ml}$, Sigma, Bornem, Belgium), was dissolved in $0.9 \% \mathrm{NaCl}$ and aminoglutethimide (Sigma, Bornem, Belgium) was dissolved in 
sterile DMSO (Sigma, Bornem, Belgium). Progesterone (Sigma, Bornem, Belgium) and RU486 (Mifepristone or Mifegyne, a generous gift from Laboratoires Exelgyn, Paris, France) were dissolved in $\mathrm{MeOH}$ and $\mathrm{EtOH}$ respectively. Dexamethasone (Sigma, Bornem, Belgium) was dissolved in sterile DMSO. Dosages were chosen based on dose-response experiments; the lowest dose with effect was used. In control cultures (M199) the medium was rinsed and refreshed with M199 as in the treated counterparts. There was no addition of vehicles to controls as the concentration of all vehicles was always kept below $0 \cdot 1 \%$ in the corresponding treated fraction. It was found in the present quail granulosa cell explants that below this concentration the used vehicles had no influence on P4 levels and cell death (data not shown).

\section{Staining and quantification of apoptotic nuclei}

GC explants were rinsed in phosphate-buffered saline (PBS, $10 \mathrm{mM}$, pH 7.4), fixed for $20 \mathrm{~min}$ in 4\% formaldehyde in PBS, again rinsed in PBS and stained using a $1 / 1000$ solution of $2^{\prime}, 6^{\prime}$-diamidino-2-phenylindole (DAPI) in PBS. Mounted GC explants were examined under a Leica DM IRB/E inverted microscope $(\times 63$ objective, $1 \cdot 0$ zoom) and apoptotic cells were identified by their characteristic fragmented chromatin masses. Small groups of apoptotic bodies were counted as remnants of one apoptotic cell. Apoptosis was expressed as the number of apoptotic nuclei per number of total nuclei counted in the same microscopic field. This apoptotic index (AI) was averaged for 10 fields giving a total number of about 1500 cells counted per treatment.

\section{Progesterone (P4) assay}

From in vitro incubation studies, it has been clarified that the primary source of $\mathrm{P} 4$ in avian species is the granulosa cell of the largest (F1) follicle, the one destined to ovulate next. In the smaller pre-ovulatory follicles, the second (F2) and the third (F3) largest follicles, P4 is rapidly metabolised due to their significant higher amounts of conversion enzymes in the theca cells (Huang \& Nalbandov 1979, Mori et al. 1984, 1985, Mori 1987).

Progesterone was measured in spent medium using an automated chemiluminescence system (Chiron Diagnostics ACS:180 P4 assay), a competitive immunoassay with a minimum detectable concentration of $0.11 \mathrm{ng} / \mathrm{ml}$ $(0.35 \mathrm{nM})$. Samples were run in several assays. The intra-assay variation is given by a covariance of $3.3 \%$ for an average value of $5.3 \mathrm{ng} / \mathrm{ml}$ and $7.9 \%$ for $10.9 \mathrm{ng} / \mathrm{ml}$; the interassay variation is $10 \cdot 1 \%$ for $6 \cdot 3 \mathrm{ng} / \mathrm{ml}$ and $10 \cdot 4 \%$ for $14 \cdot 0 \mathrm{ng} / \mathrm{ml}$. The actual precision, determined by both intra- and interassay variation, is given by a covariance of $5 \cdot 4 \%$ for $8 \cdot 1 \mathrm{ng} / \mathrm{ml}$ and $4.9 \%$ for $19 \cdot 6 \mathrm{ng} / \mathrm{ml}$.

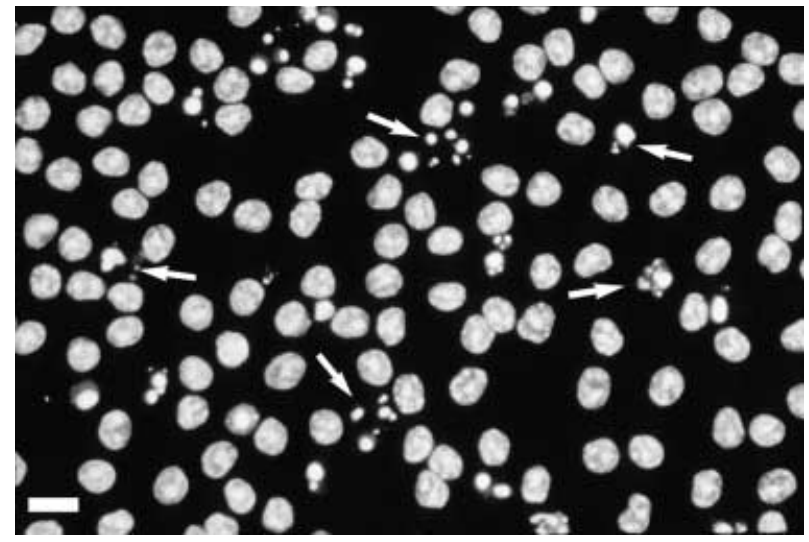

Figure 1 DAPI staining of an F1 granulosa cell explant consisting of a monolayered granulosa cell explant sandwiched between the basement and vitelline membrane. Arrows show condensed nuclear chromatin masses characteristic of apoptotic bodies. Scale bar, $10 \mu \mathrm{m}$.

\section{Identification of the progesterone receptor by Western blot analysis}

Cell explants were lysed in $200 \mu$ lysis buffer $(10 \mathrm{mM}$ Tris-HCl pH 7, 1\% NP40, $200 \mathrm{mM} \mathrm{NaCl}, 5 \mathrm{mM}$ EDTA, $1 \mathrm{mM}$ phenylmethylsulphonyl fluoride (PMSF)). Cleared cell extracts ( $30 \mu \mathrm{g}$ cellular protein) were loaded on a $15 \%$ SDS-polyacrylamide gel. After electrophoretic separation and blotting to a nitrocellulose membrane, the progesterone receptor (PR) was detected using the aPR22 monoclonal antibody (Affinity Bioreagents, Inc.), which reacts with both the $80 \mathrm{kDa} A$ form and the $110 \mathrm{kDa} B$ form of avian PR, in a 1/1000 dilution in blocking buffer (5\% dry milk in PBS containing $0.3 \%$ Tween 20) and developed by enhanced chemiluminescence (Amersham Pharmacia Biotech, UK).

\section{Statistical analysis}

Statistical analysis was done using the statistical program SPSS 6·1. (SPSS Inc.). Statistical significance was tested with the Wilcoxon rank sum test, a non-parametric test for paired samples. $P$ values less than 0.05 were considered significant. Values represent means \pm s.E.M. of at least four independent experiments.

\section{Results}

\section{The effect of medium change and FSH on apoptosis}

Apoptotic indexes of DAPI-stained granulosa explants were determined after 24, 48, 72 and $96 \mathrm{~h}$ in culture (Fig. 1), P4 levels were defined in the corresponding spent medium. Figure 2 summarises the data obtained, namely, a significant increase in $\mathrm{AI}$ with increasing culture time up 


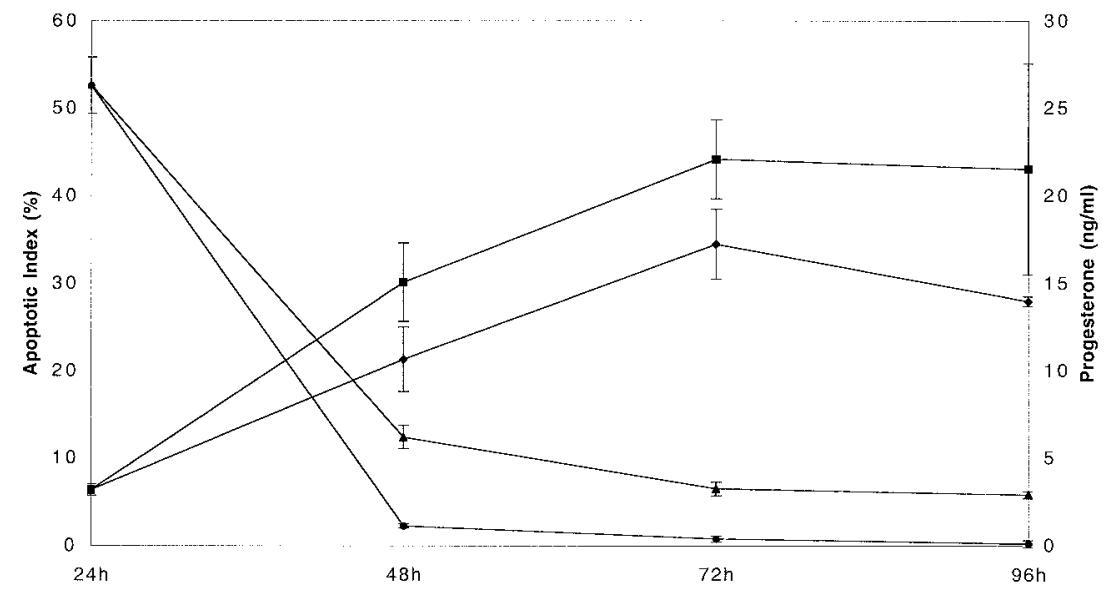

Figure 2 Effect of medium change on apoptotic indexes and P4 concentrations at the 24, 48,72 and 96 h culture stage of serum-free culture. Data represent means \pm S.E.M. Significant differences $(P<0 \cdot 05)$ are observed between changed and unchanged media conditions and between culture stages (except for $96 \mathrm{~h}: n=1) .(\diamond), \mathrm{Al}$ - medium not replaced; $(\boldsymbol{\Delta})$, P4 $(\mathrm{ng} / \mathrm{ml})$ - medium not replaced; $(\boldsymbol{\square}), \mathrm{Al}$ - medium replaced every $24 \mathrm{~h}$; (๑), P4 (ng/ml) - medium replaced every $24 \mathrm{~h}$.

to $72 \mathrm{~h}$ followed by a decrease at the $96 \mathrm{~h}$ culture stage $(P<0 \cdot 05)$. This is associated with a continuous decrease of $\mathrm{P} 4$ concentrations in the medium $(P<0 \cdot 05)$. When the medium was changed every $24 \mathrm{~h}$, thus washing out the $\mathrm{P} 4$, the AIs are significantly higher and the $\mathrm{P} 4$ concentrations significantly lower $(P<0 \cdot 05)$. The AI peak observed at $72 \mathrm{~h}$ when the medium remained unchanged was not observed when the medium was changed every $24 \mathrm{~h}$.

As the medium is replaced every $24 \mathrm{~h}$, the $\mathrm{P} 4$ values at the different time stages are the actual amounts (secretion minus consumption) present between the given culture stages. From the P4 levels it can be inferred that P4 secretion continues in serum-free culture: $1 \cdot 12 \pm 0 \cdot 12 \mathrm{ng} /$ $\mathrm{ml}$ between 24 and $48 \mathrm{~h} ; 0 \cdot 37 \pm 0 \cdot 18 \mathrm{ng} / \mathrm{ml}$ between 48 and $72 \mathrm{~h}$. After $72 \mathrm{~h}$ the $\mathrm{P} 4$ level becomes negligible $(<0 \cdot 3 \mathrm{ng} / \mathrm{ml})$.

To further assess the role of $\mathrm{P} 4$ in apoptosis, $\mathrm{P} 4$ concentrations and apoptotic indexes were determined in cultures wherein steroidogenesis was stimulated by FSH. When the medium was supplemented with FSH $(100 \mathrm{ng} / \mathrm{ml}), \quad$ P4 levels were increased 3-fold from $26.31 \pm 1.61 \mathrm{ng} / \mathrm{ml}$ in serum-free controls to $83.49 \pm 8.69 \mathrm{ng} / \mathrm{ml}(P<0 \cdot 05$, Fig. 3) together with a

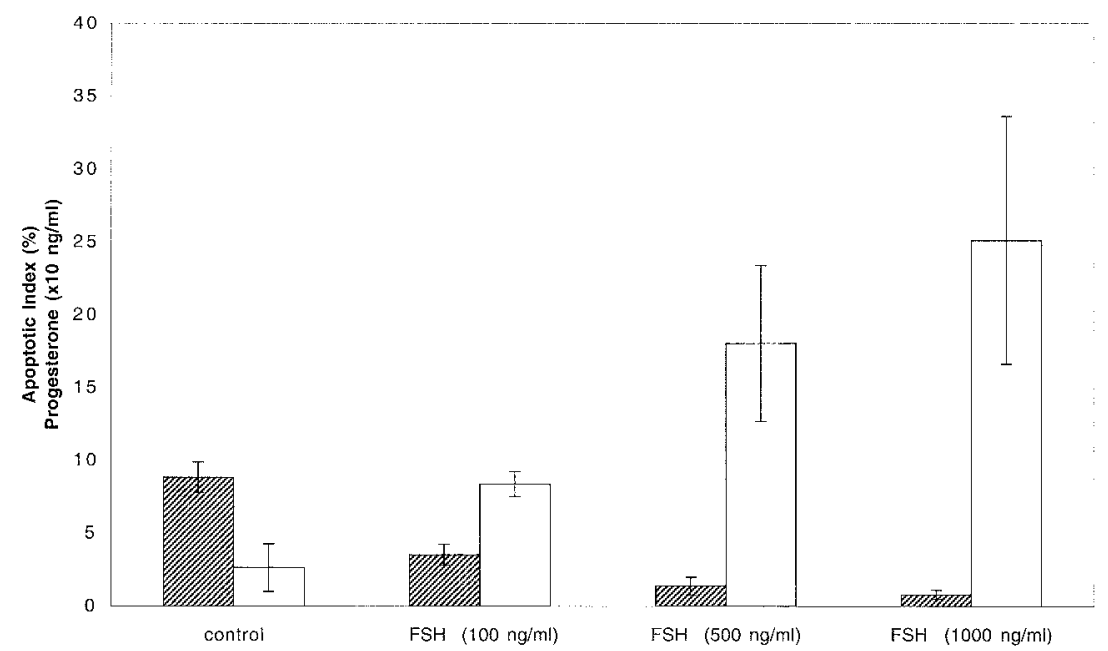

Figure 3 The dose-dependent effect of FSH on the percentage apoptosis after $24 \mathrm{~h}$ serum-free culture. Hatched columns represent Al, open columns represent P4 levels. Data represent means \pm S.E.M. 


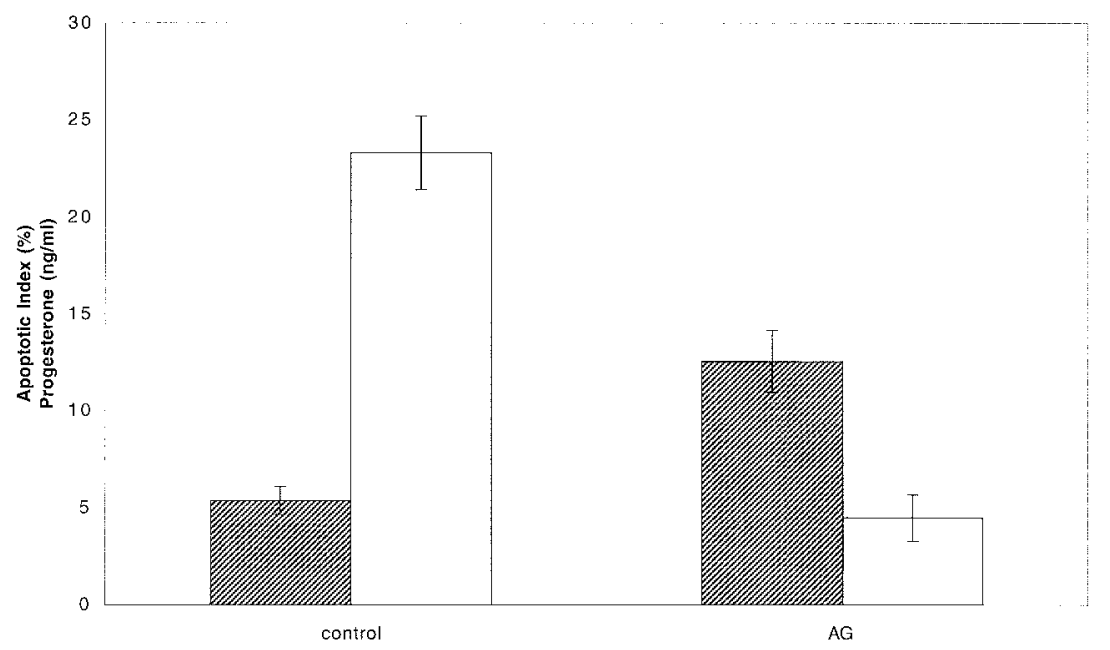

Figure 4 The apoptosis-inducing effect of AG ( $1 \mathrm{mM})$ after $24 \mathrm{~h}$ serum-free culture. Hatched columns represent Al, open columns represent P4 levels. Data represent means \pm S.E.M.

significant decrease in apoptotic indexes from $8 \cdot 81 \pm$ $1 \cdot 06 \%$ in serum-free controls to $3 \cdot 50 \pm 0 \cdot 72 \%$. The effect of FSH was dose dependent (Fig. 3); $500 \mathrm{ng} / \mathrm{ml} \mathrm{FSH}$ reduced the AI significantly to $1 \cdot 37 \pm 0 \cdot 61 \%, 1000 \mathrm{ng} / \mathrm{ml}$ made no further contribution to survival despite the further increase in P4 levels in the medium. But as the AIs were close to $0 \%$, it was difficult to measure the effect; in a single case, where AI equalled $3 \cdot 07 \%$ with $500 \mathrm{ng} / \mathrm{ml}, 1000 \mathrm{ng} / \mathrm{ml} \mathrm{FSH}$ decreased the AI another 2 - to 3-fold. To examine whether P4 is a direct cause of cell survival or is simply associated with cell survival, the effect of several inhibitors in the P4 mode of action was examined.

\section{RU486 (Mifepristone or Mifegyne) and aminogluthetimide ( $A G)$}

When the granulosa cell explants were incubated for $24 \mathrm{~h}$ with the P4 synthesis inhibitor aminogluthetimide (AG, $1 \mathrm{mM}$ ), the apoptotic process was enhanced 2-fold from $6 \cdot 08 \pm 0 \cdot 67 \%$ to $12 \cdot 55 \pm 1 \cdot 60$, together with a significant decrease in $\mathrm{P} 4$ levels in the medium $(P<0 \cdot 05$, Fig. 4). RU486 $(20 \mu \mathrm{M})$ was also effective in increasing the apoptotic indexes by blocking the $\mathrm{P} 4$ receptors: from $3.02 \pm 0.98 \%$ in serum-free controls to $17 \cdot 07 \pm 3 \cdot 20 \%$ $(P<0 \cdot 05$; Fig. 5). This was accompanied by a $50 \%$ decrease in $\mathrm{P} 4$ concentrations from $35 \cdot 83 \pm 3 \cdot 23 \%$ in serum-free controls to $16 \cdot 88 \pm 3 \cdot 59 \%$ in RU486-treated explants. To rule out the possibility that RU486 acts through binding to glucocorticoid receptors, cultures were additionally supplemented with either dexamethasone or P4. Dexamethasone (Dex) was not able to reverse the effect of RU486 whereas P4 (320-640 nM) in combination with RU486 significantly decreased AI to control values in a dose-dependent manner. Dexamethasone $(0 \cdot 1,1$ and $10 \mu \mathrm{M})$ on its own decreased AI significantly: for $1 \mu \mathrm{M}$ : from $3.02 \pm 0.98 \%$ in serum-free controls to $0.99 \pm 0.40 \%$ in Dex-treated explants (Fig. 5, P<0.05). The values for the other concentrations of Dex are similar to this result. A concentration of $0.01 \mu \mathrm{M}$ did not affect apoptosis. P4 levels were unchanged compared with serum-free controls.

\section{Exogenous progesterone (Pex) and the involvement of endogenous P4}

As expected from the above results, application of Pex should result in a direct effect on viability. Different concentrations $(640,3200$ and $6400 \mathrm{nM})$ were used during $24 \mathrm{~h}$ incubations and no significant inhibition of apoptosis compared with serum-free controls occurred although the $\mathrm{P} 4$ concentration in the medium was significantly increased from $26.31 \pm 1.61 \mathrm{ng} / \mathrm{ml}$ in serumfree controls to $177 \cdot 00 \pm 15 \cdot 56$ (Fig. 6); $832.93 \pm 72 \cdot 40$ and $1791 \cdot 00 \pm 73.76 \mathrm{ng} / \mathrm{ml}(P<0 \cdot 05$; data not shown $)$ respectively.

Inhibiting the endogenous $\mathrm{P} 4$ production for $24 \mathrm{~h}$ by simultaneously applying $1 \mathrm{mM}$ AG and Pex (640 nM) resulted in a significant 2-fold decrease in AI compared with AG experiments $(12.53 \pm 1 \cdot 60$ vs $7 \cdot 28 \pm 2 \cdot 04 \%)$. Compared with serum-free controls, the AG+Pex experiments did not enhance viability despite the significant, almost 10-fold, increase in $\mathrm{P} 4$ concentration in the medium (Fig. 6).

Adding P4 (640-3200 nM) between 48 and $72 \mathrm{~h}$, when endogenous P4 production is low $(6 \cdot 19 \pm 0 \cdot 66$ vs $26.31 \pm 1.61 \mathrm{ng} / \mathrm{ml}$ at $24 \mathrm{~h}$ ) results in a significant decrease in AI compared with serum-free controls $(P<0 \cdot 05$, 

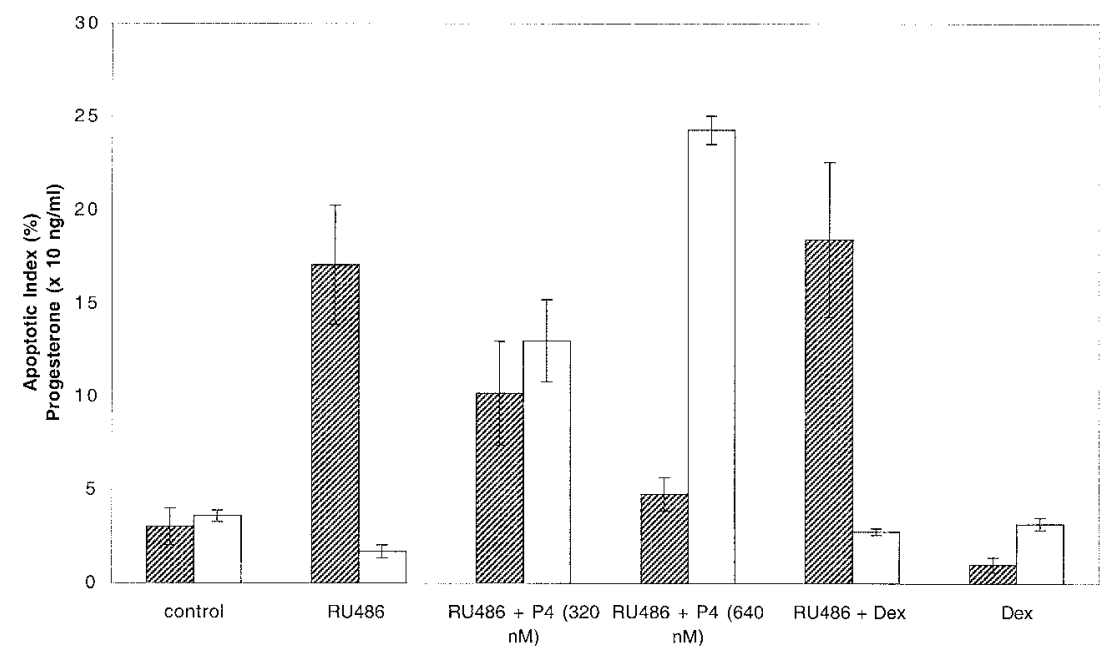

Figure 5 The effects of RU486 $(20 \mu \mathrm{M})$ and Dex on apoptosis after $24 \mathrm{~h}$ serum-free culture. Hatched columns represent Al, open columns represent P4 levels. Data represent means \pm S.E.M.

Fig. 7). Assaying Pex at different culture stages (24, 48, 72 and $96 \mathrm{~h}$ ) in M199 medium without granulosa explants shows that there is no spontaneous degradation of $\mathrm{P} 4$ (data not shown).

FSH combined with aminogluthetimide: a possible P4-independent survival pathway?

As FSH is able to block apoptosis and to stimulate P4 secretion and Pex only affects survival when endogenous secretion is experimentally inhibited or falls spontaneously in prolonged culture, then the existence of a FSH-induced survival pathway acting independently of $\mathrm{P} 4$ can be hypothesised. Experiments were designed to test the hypothesis: $24 \mathrm{~h}$ cultures supplemented with FSH $(100 \mathrm{ng} / \mathrm{ml})$ in combination with AG $(1 \mathrm{mM})$. Surprisingly, results show a significant decrease in AI compared with serum-free controls (from $6 \cdot 08 \pm 0.67 \%$ in serumfree controls to $1.64 \pm 0.71 \%$ ) even though there is a significant decrease in $\mathrm{P} 4$ from $26 \cdot 31 \pm 1 \cdot 61$ to $8.73 \pm 1.99 \mathrm{ng} / \mathrm{ml}$. The decrease in AI is comparable to the decrease obtained by FSH supplementation alone although in the latter the $\mathrm{P} 4$ production is about eight times higher (Fig. 8).

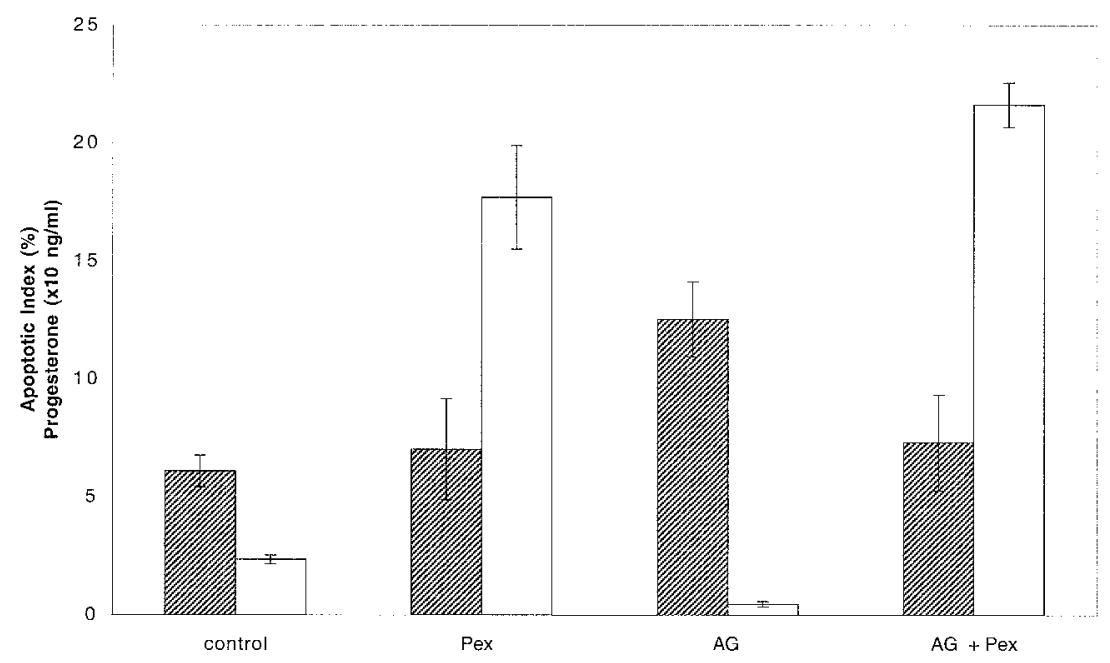

Figure 6 The effects of Pex $(640 \mathrm{nM})$ and AG $(1 \mathrm{mM})$ after $24 \mathrm{~h}$ serum-free culture. Hatched columns represent $\mathrm{Al}$, open columns represent $\mathrm{P} 4$ levels. Data represent means \pm S.E.M. 


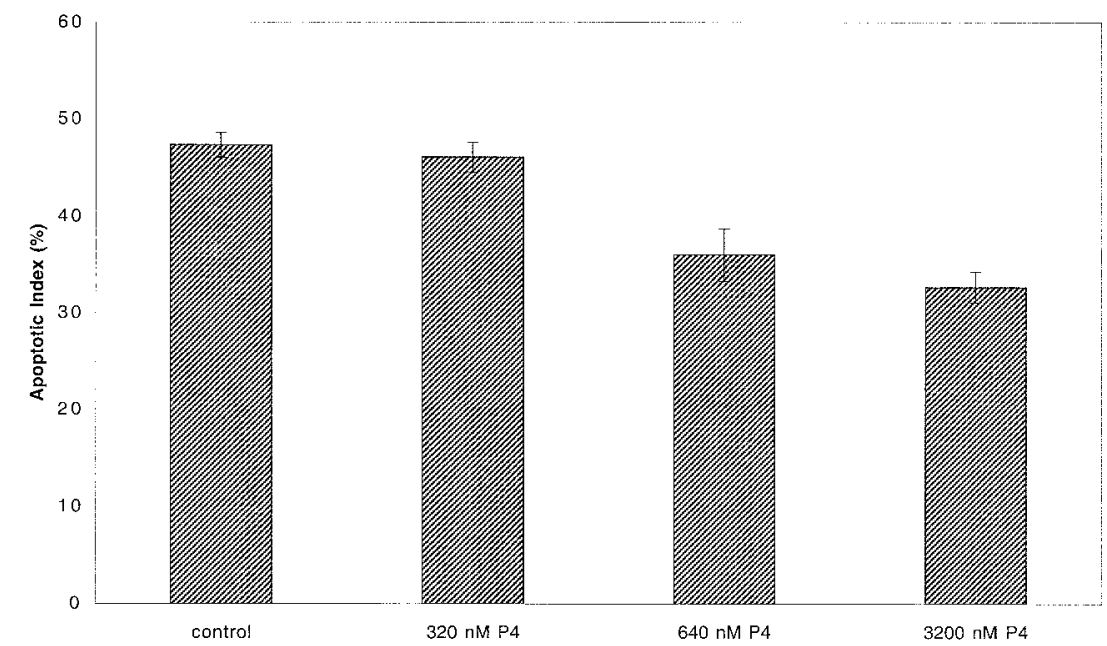

Figure 7 The effect of $24 \mathrm{~h}$ P4 supplementation ( $320 \mathrm{nM}, 640 \mathrm{nM}, 3200 \mathrm{nM}$ ) on apoptosis after $48 \mathrm{~h}$ of serum-free culture. Hatched columns represent Al. Data represent means \pm S.E.M.

\section{Identification of the progesterone receptor by Western blotting}

The presence of the A (PR-A) and $\mathrm{B}(\mathrm{PR}-\mathrm{B})$ form of the $\mathrm{PR}$ was investigated at $0,24,48$ and $72 \mathrm{~h}$ of serum-free culture by Western blotting using a monoclonal antibody against both forms of the avian PR. Figure 9 shows a strong signal at all culture stages tested of $110 \mathrm{kDa}$ representing PR-B and a weak signal representing the $78 \mathrm{kDa}$ PR-A.

\section{Discussion}

The present study examined whether $\mathrm{P} 4$ acts as an autocrine/paracrine survival factor in serum-free cultured granulosa explants isolated from the largest pre-ovulatory follicle of the quail. The use of an avian model for endocrine studies is interesting because of the hierarchical arrangement of the pre-ovulatory follicles, which allows an easy identification of the maturational stage of the follicle and prediction of time of ovulation. Secondly, the theca (the site of androgen and oestrogen production) and granulosa (the source of P4) layers can easily be separated without contamination (Bahr 1990). Apoptosis was assessed by DAPI staining disclosing the typical morphological features of apoptotic nuclei. Apoptotic morphological features were also confirmed at the ultrastructural level in $72 \mathrm{~h}$ cultured quail granulosa explants (D'Herde et al. 2000). It was previously shown for avian granulosa that methods detecting chromatin condensation and

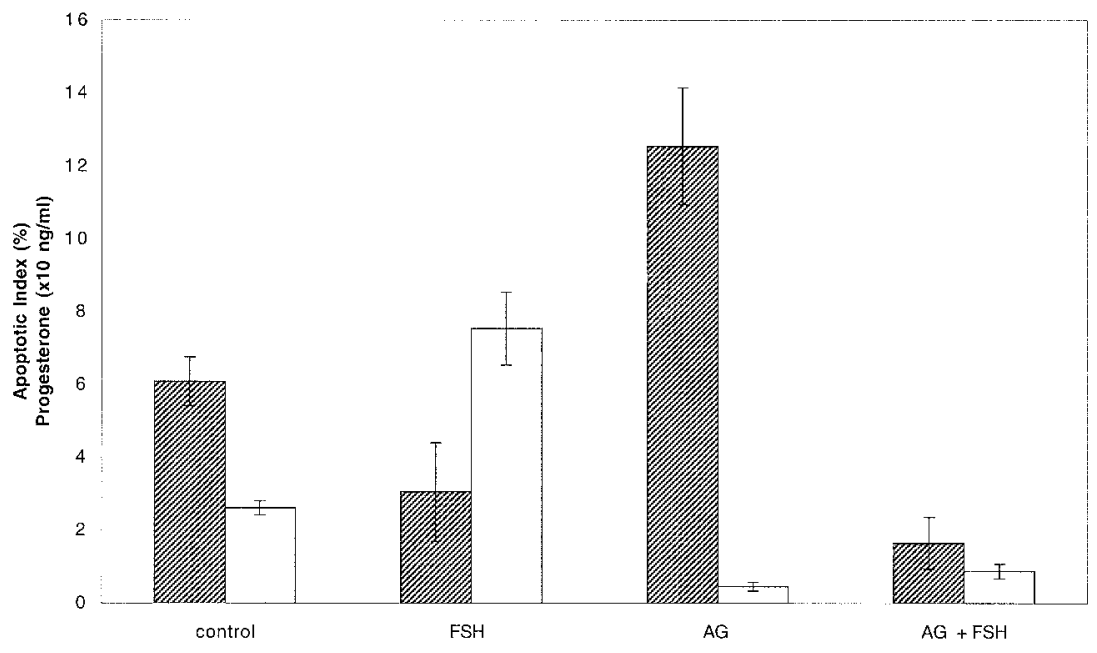

Figure 8 The effect of FSH $(100 \mathrm{ng} / \mathrm{ml})$ combined with AG $(1 \mathrm{mM})$ after $24 \mathrm{~h}$ serum-free culture. Hatched columns represent $\mathrm{Al}$, open columns represent $\mathrm{P} 4$ levels. Data represent means \pm S.E.M. 


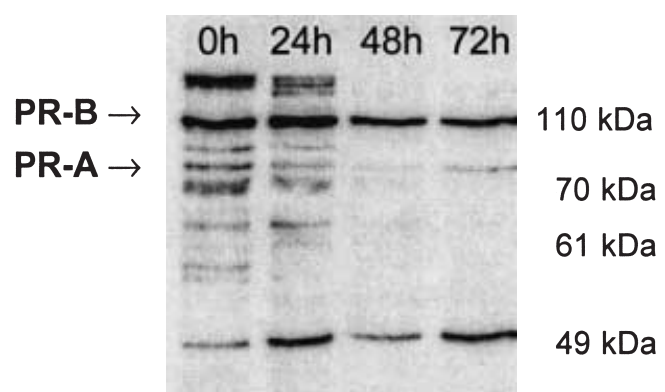

Figure 9 Western blot of the avian PR in granulosa cell explant of the largest preovulatory follicle (F1) at $0,24,48$ and $72 \mathrm{~h}$.

fragmentation are more reliable for quantification of apoptosis than methods using in situ end labelling (D'Herde et al. 1994). Granulosa cell explants cultured up to $96 \mathrm{~h}$, show an increase of apoptotic indexes peaking at $72 \mathrm{~h}$ whereafter a subpopulation was selected which is resistant to gonadotropin withdrawal (D'Herde \& Leybaert 1997).

In the present study $\mathrm{P} 4$ levels were compared with apoptotic indexes. An inverse relationship was found between P4 levels and AI up to $72 \mathrm{~h}$. At 96 h, however, when AI declines in the unchanged cultures, P4 levels are not restored probably because of dedifferentiation or reduced steroidogenic capacities of the surviving cells. One has to bear in mind that the P4 found in the medium results from secretion and uptake by the cells for further metabolisation as there is no spontaneous degradation of $\mathrm{P} 4$ in the medium. By replacing the medium every $24 \mathrm{~h}$ and thus washing out $\mathrm{P} 4$, one obtains some idea of the actual production during the different culture stages, assuming that the consumption of $\mathrm{P} 4$ is constant. The data indicate that quail granulosa cells remain steroidogenically productive until $72 \mathrm{~h}$ of serum-free culture, after that the $\mathrm{P} 4$ level becomes negligible. Peddie et al. (1994) cultured chicken granulosa cells for up to $72 \mathrm{~h}$ without changing the medium daily and found that basal $\mathrm{P} 4$ accumulation in the medium increased over $24-48 \mathrm{~h}$ in culture and then tended to decline. The $\mathrm{P} 4$ secretion in vitro was not expected since in vivo the collected F1 granulosa cells $(2 \mathrm{~h}$ before ovulation) will be poised to deteriorate following follicle rupture at ovulation.

To determine whether $\mathrm{P} 4$ can act as a survival factor in the granulosa system it was first investigated whether the progesterone receptor (PR) is expressed in the F1 granulosa explants. Western blot analysis was performed using a monoclonal antibody against both the A and $\mathrm{B}$ forms of chicken PR. Yoshimura \& Bahr (1991) described the presence of PR in granulosa cells of F1 of the domestic hen. This phenomenon is paralleled by the higher P4 production through the follicle hierarchy (see Materials and Methods) indicating a possible important target function of the pre-ovulatory granulosa layer for
P4 in addition to the more traditionally accepted target tissues of $\mathrm{P} 4$ like the uterus and the mammary gland. The $110 \mathrm{kDa}$ PR-B and $78 \mathrm{kDa}$ PR-A isoforms were present in the granulosa explants from the F1 follicle at all culture stages tested $(0,24,48$ and $72 \mathrm{~h})$. PR-A is known to appear sometimes as a very faint band (D Toft, personal communication). The presence of both $\mathrm{PR}$ isoforms is in accordance with the findings for granulosa cells of the domestic hen (Yoshimura \& Bahr 1991). In most mammalian models PR-A is transcriptionally inactive and acts as a potent transdominant repressor of PR-B-mediated transcription and of other steroid receptor activity (Vegeto et al. 1993). However, although both $\mathrm{A}$ and $\mathrm{B}$ forms of mammalian and avian PR are very similar, Giangrande et al. (1997) showed that the mechanism of action of the $\mathrm{PR}$ in both models are quite different due to the lack of the repressor function of PR-A in chicken. The Western blot analysis also reveals a large amount of background probably consisting of heat-shock (hsp70, hsp90) and other proteins including p50 and p53, known to be associated with the inactivated chicken PR (Schowalter et al. 1991). In Fig. 9, the band above $110 \mathrm{kDa}$ in lanes 1 and 2 most likely represents PR still bound to hsp90 or other proteins.

The higher apoptotic indexes obtained by washing out $\mathrm{P} 4$ are in agreement with the hypothesis of $\mathrm{P} 4$ being a survival factor in the granulosa explants. As described by Hsueh et al. (1984), FSH regulates progesterone biosynthesis by modulating the activities of various steroidogenic enzymes. Accordingly, when the medium was supplied with FSH, an increase in P4 levels in the medium and an inhibition of apoptosis when compared with serum-free controls was observed. Both effects of FSH on steroidogenesis and survival are dose dependent. Although preovulatory follicles are largely under the control of LH via the dominant expression of the LH receptor, FSH was used to stimulate $\mathrm{P} 4$ production as FSH was utilised successfully in earlier studies to inhibit apoptosis (D'Herde \& Leybaert 1997, D'Herde et al. 2000). In these papers, several effects of FSH with respect to apoptosis signal transduction are well documented. As FSH affects a myriad of processes in cultured granulosa cells (reviewed by Hsueh et al. 1984), which could also be responsible for apoptosis inhibition, dependent or not on $\mathrm{P} 4$, it was necessary to further elucidate the involvement of P4 in FSH-mediated cell survival. Additional evidence for the apoptosis-inhibiting role of $\mathrm{P} 4$ came from the experiments with AG and RU486. When P4 synthesis was blocked by inhibiting the side-chain cleavage step from cholesterol to pregnenolone by $\mathrm{AG}$ or when the $\mathrm{P} 4$ receptors are occupied by RU486, the AI are higher than in serum-free controls. This means that apoptosis is induced by omitting protection of $\mathrm{P} 4$ and moreover, that the hormone operates through its receptors. Blocking of the receptors by RU486 was accompanied by a decrease in P4 levels measured in the medium. This direct action of RU486 on luteal 
function, besides their antagonism at the progesterone receptor level was previously observed by Singh et al. (1988) in adult female rats. Analogous apoptosis induction was reported previously in isolated rat granulosa cell cultures (Luciano et al. 1994, Peluso and Pappalardo 1999) as well as in human granulosa cells (Makrigiannakis et al. 2000). Although RU486 is a P4 receptor antagonist, a partial agonist function is described depending on the cell type used (Vegeto et al. 1996, 1999, Nordeen et al. 1995, Omigbodum et al. 1997). Paradoxical agonist effects of the PR antagonist RU486, a persistent clinical problem, were not observed at the $24 \mathrm{~h}$ culture stage. As P4 and RU486 are known to have antiglucocorticoid action as well, RU486-treated cultures were additionally supplemented with dexamethasone (Dex), a potent glucocorticoid hormone analogue, or P4 to exclude influence of the glucocorticoid receptor (GR). It can be concluded that, if the glucocorticoid receptor agonist Dex was not able to reverse the effect of RU486 while P4 could, P4-mediated survival occurs via the progesterone receptor. Supposing that both P4 and RU486 operate through the glucocorticoid receptor then both treatments should result in an increase of AI, which is not the case for P4. Dex suppressed apoptosis significantly without affecting P4 levels in contrast to its apoptosis-inducing effect in thymocytes, pointing to a separate survival pathway in the granulosa model. This apoptosis-inhibiting effect of Dex is found in several other models, some in conjunction with a P4-survival pathway, such as in mouse mammary glands (Feng et al. 1995), neutrophils (human: Liles et al. 1995; rat: Meagher et al. 1996, Nittoh et al. 1998), mouse uterine epithelial cell (Jo et al. 1993) and in rat hepatoma cells (Yamamoto et al. 1998, Evans-storms \& Cidlowski 2000). In serum-free cultured human granulosa cells Dex treatment did not affect survival (Makrigiannakis et al. 2000). Hsueh et al. (1984) describes the ability of Dex to enhance P4 biosynthesis in cultured rat granulosa cells but this was tested in combination with FSH supplementation. However, in the present study, no difference was observed in P4 levels in the medium of serum-free controls and Dex-treated explants.

As blocking of the $\mathrm{P} 4$ receptors causes the cells to go into apoptosis and FSH-stimulated $\mathrm{P} 4$ production causes survival, one would expect that exogenous supplied P4 (Pex) would invariably promote cell survival. This is the case for rat large granulosa cells where administration of Pex is sufficient to prevent apoptosis in vitro and where this effect could be attenuated by RU486 but not by AG (Luciano et al. 1994). Although AG and RU486 induce apoptosis in quail granulosa explants, no significant protection on viability by Pex alone can be observed in the $24 \mathrm{~h}$ cultures as compared with serum-free controls. Analogous results were found by Rueda et al. (2000) for bovine luteal cells. Both AG and RU486 treatment induced apoptosis, whereby the AG effect could be attenuated by Pex. Pex treatment alone, however, did not affect survival as compared with serum-free controls. In accordance with the present study basal P4 levels under serum-free conditions were high $(>100 \mathrm{ng} / \mathrm{ml})$; this in contrast to the low P4 levels $(6.30 \pm 0.70 \mathrm{ng} / \mathrm{ml})$ in rat granulosa cells where Pex has a survival effect (Luciano et al. 1994). As an explanation as to why supplementation with Pex does not affect survival one can argue that $\mathrm{P} 4$ receptors are saturated in the $24 \mathrm{~h}$ serum-free cultured granulosa explants in line with the P4 output at this stage $(26.31 \pm 1.61 \mathrm{ng} / \mathrm{ml}$; for reference (Onagbesan \& Peddie 1988): in quail serum P4 levels around $2.52 \mathrm{ng} / \mathrm{ml}$ are the threshold value for inducing ovulation), so that exogenous $\mathrm{P} 4$ has no effect as long as there is no substantial drop in endogenous P4 secretion. Further evidence for this state of saturation at the $24 \mathrm{~h}$ culture stage is shown in the experiment where P4, added at $48 \mathrm{~h}$ when endogenous $\mathrm{P} 4$ levels are substantially decreased $(6.19 \pm 0.66$ versus $26.31 \pm 1.61 \mathrm{ng} / \mathrm{ml}$ at $24 \mathrm{~h}$ ), indeed influenced survival. Secondly, Pex can have a suppressive effect on the expression of its own receptors (Clark \& Markaverich 1988). To test these two concepts experiments were designed with combinations of $A G$ and Pex. Where Pex had no effect on survival, Pex in combination with AG did have an effect on survival. The fact that Pex could reverse the AG inhibition of P4 synthesis confirms the specificity of AG and the antiapoptotic capacity of $\mathrm{P} 4$ in non-saturated PR conditions. Moreover it proves that in the present study AG did not exert a general toxic effect.

As FSH is able to stimulate both $\mathrm{P} 4$ and survival, it could be that (1) FSH triggers expression of P4 receptors as in rat granulosa cells (Natraj \& Richards 1993), probably under cAMP control, or (2), the FSH effect is not entirely P4 dependent. FSH-stimulated production of oestrogens, a known survival factor in other ovarian model systems (Peluso et al. 1981, Hsueh et al. 1984, Billig et al. 1994, Vegeto et al. 1999), can be excluded as this steroid is not produced in the avian granulosa cells but in the theca cells (Bahr 1990). Without excluding a mediating role for the $\mathrm{P} 4$ receptors, evidence for a $\mathrm{P} 4$-independent survival pathway came from experiments where AG is combined with FSH. The stimulating effect of FSH on P4 secretion was inhibited by AG but its protecting effect was still present meaning that FSH can inhibit apoptosis even when P4 synthesis is blocked. In rat granulosa cells the only P4-independent survival pathway elucidated hitherto is the effect of cell contact through adhesion type junctions (Peluso et al. 1996).

In conclusion the data presented in this article are in line with the hypothesis that at least two distinct survival pathways maintain granulosa cell viability in the studied in vivo-like model system. First a P4-dependent survival pathway under gonadotropic control, whereby P4 acts as an autocrine/paracrine survival factor mediating its effect at receptor level. Secondly a P4-independent survival pathway influenced either by FSH or by glucocorticoids. 


\section{Acknowledgements}

We wish to thank Christophe Van Steenkiste, Tom Van Maerken and Jill Vanmassenhove for excellent technical assistance. This study was supported by the Belgian BOZF (no. 01106797 to F Roels and no. 01115799 to K D’Herde). We also thank Frank Roels for helpful discussion, and Christophe Van Steenkiste, Tom Van Maerken and Jill Vanmassenhove for excellent technical assistance. We are also very grateful to Peter Schotte for help with the Western blotting.

\section{References}

Bahr J 1990 The avian ovary: model for endocrine studies. The Journal of Experimental Zoology Supplement 4 192-194.

Billig H, Furuta I \& Hsueh AJW 1994 Estrogens inhibit and androgens enhance ovarian granulosa cell apoptosis. Endocrinology $1332204-2212$

Chaffkin LM, Luciano AA \& Puluso JJ 1992 Progesterone as an autocrine/paracrine regulator of human granulosa cell proliferation. Journal of Clinical and Endocrinological Metabolism 75 1404-1408.

Chappell PE, Lydon JP, Conneely OM, O'Malley BW \& Levine JE 1997 Endocrine defects in mice carrying a null mutation for the progesterone receptor gene. Endocrinology 138 4147-4152.

Chun SY \& Hsueh AJW 1998 Paracrine mechanisms of ovarian follicle apoptosis. The Journal of Reproductiove Immunology 39 63-75.

Clark JH \& Markaverich BM 1988 Actions of ovarian steroid hormones. In The Physiology of Reproduction, pp 675-724. Eds E Knobil, JD Neill, LL Ewing, GS Greenwald, CL Markert \& DW Pfaff. New York: Raven Press.

Criel G \& D'Herde K 1996 Programmed cell death of the nurse cells at the end of vitellogenesis in the ovary of the brine shrimp Artemia Franciscana. Proceedings of the Joint Meeting BVM/NVvM, Ghent 1996, pp 118-125.

D'Herde K \& Leybaert L 1997 Intracellular free calcium related to apoptotic cell death in quail granulosa cell sheets kept in serum-free culture. Cell Death and Differentiation 4 59-65.

D'Herde K, De Pestel G \& Roels F 1994 In situ end labeling of fragmented DNA in induced ovarian atresia. Biochemistry and Cell Biology 72 573-579.

D'Herde K, De Prest B, Mussche S, Schotte P, Beyaert R, Van Coster R \& Roels F 2000 Ultrastructural localization of cytochrome $\mathrm{c}$ in apoptosis demonstrates mitochondrial heterogeneity. Cell Death and Differentiation 7 331-337.

Evans-storms R \& Cidlowski JA 2000 Delineation of an antiapoptotic action of glucocorticoids in hepatoma cells: the role of nuclear factor-КB. Endocrinology 141 1854-1862.

Farioli-Vecchioli S, Raes S, Espeel M, Roels F \& D’Herde K 2000 Inversed expression of peroxisomes and connexin- 43 in the granulosa cells of the quail follicle. The Journal of Histochemistry and Cytochemistry 48 167-177.

Feng Z, Marti A, Jehn B, Altermatt HJ, Chiciza G \& Jaggi R 1995 Glucocorticoid and progesterone inhibit involution and programmed cell death in the mouse mammary gland. Journal of Cell Biology 131 1095-1103.

Giangrande PH, Pollio G \& McDonnell DP 1997 Mapping and characterization of the functional domains responsible for the differential activity of the A and B isoforms of the human progesterone receptor. The Journal of Biological Chemistry 272 32889-32900.

Gilbert AB, Evans AJ, Perry MM \& Davidson MH 1977 A method for separating the granulosa cells, the basal lamina and the theca of the preovulatory ovarian follicle of the domestic fowl (Gallus domesticus). The Journal of Reproduction and Fertility $\mathbf{5 0}$ 79-81.

Hosokawa K, Dantes A, Schere-Lewy C, Barash A, Yoshida Y, Kotsuji F, Vlodasky I \& Amsterdam A 1998 Induction of Ad4PB/SF-1, steroidogenic acute regulatory protein, and cytochrome P450 scc enzyme system expression in newly established human granulosa cell lines. Endocrinology 139 4679-4687.

Hsu SY \& Hsueh AJW 1997 Hormonal regulation of apoptosis. Trends in Endocrinology and Metabolization 8 207-213.

Hsueh AJW, Adashi EY, Jones PBC \& Welsh TH 1984 Hormonal regulation of the differentiation of cultured ovarian granulosa cells. Endocrine Review 5 76-127.

Huang ESR \& Nalbandov AV 1979 Steroidogenesis of chicken granulosa and theca cells: in vitro incubation system. Biology of Reproduction 20 442-453.

Isola JJ 1987 The effect of progesterone on the localization of progesterone receptors in the nuclei of chick oviduct cells. Cell and Tissue Research 249 317-323.

Isola J, Ylikomi T \& Tuohimaa P 1986 Nuclear origin of progesterone receptor of the chick oviduct cytosol. An immunoelectron microscopy study. Histochemistry 86 53-58.

Isola J, Korte JM \& Tuohimaa P 1987a Immunocytochemical localization of progesterone receptor in the chick ovary. Endocrinology 121 1034-1040.

Isola J, Pelto-Huikko M, Ylikomi T \& Tuohimaa P 1987 b Immunoelectron microscopic localization of progesterone receptor in the chick oviduct. Journal of Steroid Biochemistry 26 19-23.

Jo T, Terada N, Saji F \& Tanizawa O 1993 Inhibitory effects of estrogen, progesterone, androgen and glucocorticoid on death of neonatal mouse uterine epithelial cells induced to proliferate by estrogen. Journal of Steroid Biochemistry and Molecular Biology 46 25-32.

Kuranaga THE, Kanuka H, Hirabayashi K, Suzuki M, Nishihara M \& Takahashi M 2000 Progesterone is a cell death supressor that downregulates Fixed assets expression in rat corpus luteum. FEBS Letters 466 279-282.

Liles WC, Dale DC \& Klebanoff SJ 1995 Glucocorticoids inhibit apoptosis in human neutrophils. Blood 8 3181-3188.

Luciano AM, Pappalardo A, Ray C \& Peluso JJ 1994 Epidermal growth factor inhibits large granulosa cell apoptosis by stimulating progesterone synthesis and regulating the distribution of intracellular free calcium. Biology of Reproduction 51 646-654.

Lydon JP, DeMayo FJ, Funk CR, Mani SK, Hughes AR, Montgomery CA Jr, Shyamala G, Conneely OM \& O'Malley BW 1995 Mice lacking progesterone receptor exhibit pleiotropic reproductive abnormalities. Genes and Development 9 2266-2278.

Makrigiannakis A, Coukos G, Christofidou-Solomidou M, Montas S \& Coutifaris C 2000 Progesterone is an autocrine/paracrine regulator of human granulosa cell survival in vitro. Annals of the New York Academy of Sciences 900 16-25.

Marrrone BL \& Crissman HA 1988 Characterization of granulosa cell subpopulations from avian preovulatory follicles by multiparameter flow cytometry. Endocrinology 122 651-658.

Meagher LC, Cousin JM, Seckl JR \& Haslett C 1996 Opposing effects of glucocorticoids on the rate of apoptosis in neutrophilic and eosinophilic granulocytes. The Journal of Immunology 156 4422-4428.

Mori M 1987 Changes in activities of $17 \beta$-hydroxysteroid dehydrogenase and $5 \beta$-reductase in theca cells during the ovulatory cycle of the laying Japanese quail. Japanese Poultry Science 24 313-315.

Mori M, Kohmoto K \& Shoda Y 1984 Role of granulosa and theca cells on in vitro progesterone production in preovulatory follicles of the Japanese quail. Japanese Poultry Science 21 206-214.

Mori M, Aoto F, Kohmoto K \& Shoda Y 1985 Metabolism of steroid hormones in vitro by follicular tissues of the Japanese quail. Biology of Reproduction 33 11-20. 
Natraj U \& Richards JS 1993 Hormonal regulation, localization, and functional activity of the progesterone receptor in granulosa cells of rat preovulatory follicles. Endocrinology 133 761-769.

Nittoh T, Fujimori H, Kozumi Y, Ishihara K, Mue S \& Ohuchi K 1998 Effects of glucocorticoids on apoptosis of infiltrated eosinophils and neutrophils in rats. European Journal of Pharmacology 354 73-81.

Nordeen SK, Bona BJ, Beck CA, Edwards DP, Borror KC \& DeFranco DB 1995 The two faces of a steroid antagonist: when an antagonist isn't. Steroids 60 97-104.

Omigbodun A, Ziolkiewicz P, Tessler C, Hoyer JR \& Coutifaris C 1997 Progesterone regulates osteopontin expression in human trophoblasts: a model of paracrine controls in the placenta? Endocrinology 138 4308-4315.

Onagbesan OM \& Peddie MJ 1988 Induction of ovulation and oviposition in female quail with luteinizing hormone, luteinizing hormone releasing hormone, or progesterone. General and Comparative Endocrinology 71 124-131.

Park O-K \& Mayo KE 1991 Transient expression of progesterone receptor messenger RNA in ovarian granulosa cells after the preovulatory luteinizing hormone surge. Molecular Endocrinology $\mathbf{5}$ 967-978.

Peddie MJ, Onagbesan OM \& Williams J 1994 Chicken granulosa cell proliferation and progesterone production in culture: effects of EGF and theca secretions. General and Comparative Endocrinology 94 341-356.

Peluso JJ 1997 Placing progesterone in the apoptotic pathway. Trends in Endocrinology and Metabolization 8 267-271.

Peluso JJ \& Pappalardo A 1999 Progesterone maintains large rat granulosa viability indirectly by stimulating small granulosa cells to synthesize basic fibroblast growth factor. Biology of Reproduction $\mathbf{6 0}$ 290-296.

Peluso JJ, Charlesworth J \& England-Charlesworth C 1981 Role of estrogen and androgen in maintaining the preovulatory follicle. Cell and Tissue Research 216 615-624.

Peluso JJ, Pappalardo A \& Trolice MP 1996 N-cadherin-mediated cell contact inhibits granulosa cell apoptosis in a progesteroneindependent manner. Endocrinology 137 1196-1203.

Richards JS 1994 Hormonal control of gene expression in the ovary. Endocrine Reviews 15 725-751.

Rueda BR, Hendry IR, Hendry WJ III, Stormshak F, Slayden OD \& Davis JS 2000 Decreased progesterone levels and progesterone receptor antagonists promote apoptotic cell death in bovine luteal cells. Biology of Reproduction 62 269-276.

Schowalter DB, Sullivan WP, Maihle NJ, Dobson ADW, Conneely OM, O'Malley BW \& Toft DO 1991 Characterization of progesterone receptor binding to the $90-$ and $70-\mathrm{kDa}$ heat shock proteins. The Journal of Biological Biochemistry 266 21165-21173.

Singh G, Singh MM, Maitra SC, Elgert W, Kalra V, Upadhyay SN, Choxdhury SR \& Kamboj VP 1988 Luteolytic action of two antiprogestational agents (RU-38486 and ZK-98734) in the rat. The Journal of Reproduction and Fertility 83 73-83.

Tilly JL, Tilly KI \& Perez GI 1997 The genes of cell death and cellular susceptibility to apoptosis in the ovary: a hypothesis. Cell Death and Differentiation 4 180-187.

Tischkau SA \& Bahr JM 1996 Avian germinal disc region secretes factors that stimulate proliferation and inhibit progesterone production by granulosa cells. Biology of Reproduction $\mathbf{5 4}$ 865-870.

Vegeto E, Shahbaz MM, Wen DX, Goldman ME, O'Malley BW \& McDonnell DP 1993 Human progesterone receptor A form is a cell- and promotor-specific repressor of human progesterone receptor B function. Molecular Endocrinology 7 1244-1255.

Vegeto E, Wagner BL, Imhof MO \& McDonnell DP 1996 The molecular pharmacology of ovarian steroid receptors. Vitamins and Hormones 52 99-128.

Vegeto E, Pollio G, Pellicciari C \& Maggi A 1999 Estrogen and progesterone induction of survival of monoblastoid cells undergoing TNF- $\alpha$-induced apoptosis. FASEB Journal 13 793-803.

Yamamoto M, Fukuda K, Miura N, Suzuki R, Kido T \& Komatsu Y 1998 Inhibition by dexamethasone of transforming growth factor $\beta 1$-induced apoptosis in rat hepatoma cells: a possible association with bcl-xL induction. Hepatology 27 959-966.

Yoshimura Y \& Bahr JM 1991 Localization of progesterone receptors in pre- and postovulatory follicles of the domestic hen. Endocrinology 128 323-330.

Received in final form 22 December 2000 Accepted 12 January 2001 